\title{
Nutritional evaluation of Syagrus coronata kernels and development of cookies prepared with cassava flour and licuri kernels
}

\author{
Rosemar ANTONIASSI ${ }^{1 \star ~(D), ~ P r i s c i l a ~ C o u t i n h o ~ M I R A N D A ², ~ G l e i z e ~ F i a e s ~ F E R R E I R A ~}{ }^{3}$, \\ Thais Maria Ferreira Souza VIEIRA ${ }^{4}$, Sidinea Cordeiro de FREITAS ${ }^{1}$, \\ Marilia Ieda da Silveira Folegatti MATSUURA ${ }^{5}$
}

\begin{abstract}
Syagrus coronata known as licuri, ouricuri, or uricuri is a palm tree from dried areas in Brazil and it is an important resource for the local population. The objective of this work was to evaluate the nutritional value of licuri kernels from the Territory of Sisal (State of Bahia) and to develop cookies prepared with licuri kernels and cassava flour. The licuri kernel showed high content of total dietary fiber (13 - 15\%) with values equivalent to that observed for coconut kernel. The content of minerals such as zinc, magnesium, phosphorus, manganese, iron, and copper was similar to those recorded for commercial nuts and superior to coconut kernel. The licuri kernel presented an oil content of $61-66 \%$, with a predominance of lauric acid. The main sterols were Sitosterol, Campesterol and $\Delta 5$-avenasterol. The formulations of cookies with licuri kernel (5 and $10 \%)$ and commercial cassava flour (4.5 and 9\%) showed no differences in general acceptance, aroma, flavor, and texture. The kernel of Syagrus coronata represents an important source of dietary fiber, lipids, and minerals and the results indicate that besides its traditional application, this use represents the increasing the nutritional value of cookies in compliance with global trends.
\end{abstract}

Keywords: dietary fiber; zinc; magnesium; lauric oil; sterols.

Practical Application: Data concerning nutritional value of licuri kernels and its application as an ingredient of cookies are interesting for consumers and may added value to a product of Brazilian biodiversity leading to an increase in income of the collectors.

\section{Introduction}

Syagrus coronata (Mart) Becc is a palm of Arecaceae family, native and endemic to the Brazilian territory and it can be found in the Northeast (Pernambuco, Alagoas, Sergipe, Bahia State) and Southeast (Minas Gerais State) regions of Brazil (Soares, 2020). This palm grows in the arid conditions of the Brazilian "Caatinga" region with limited water availability and it provides the raw material for the manufacture of a wide range of products in the regions where agriculture is restricted (Santos Moura et al., 2016).

This palm presents medium size, from 8 to 12 meters high and the diameter of the stipe between 20 and 40 centimeters (Gomes et al., 2018). Crepaldi et al. (2001) reported a bunch with 1347 fruits with average length and diameter of 2 and $1.4 \mathrm{~cm}$, respectively. The fruits are ovoid to ellipsoid drupes with fibrous epicarp, yellow to orange pulp, woody endocarp, and endosperm that changes from liquid to solid as the kernel mature (Gomes et al., 2018; Santos Moura et al., 2016).

Syagrus coronata palm is called as licuri and its parts are currently used by the traditional population for construction, handicrafts, as food, to feed domestic animals and wild animals (ex. Lear's Macaw), and as fuel. The fruits are edible and the kernel is used to produce an extract (called as "milk"), to produce candies and for oil extraction (Crepaldi et al., 2004; Lima-Rufino et al., 2008; Andrade Martins et al., 2015). The medicinal applications have been evaluated and the aqueous extract of fruit peels presented antileishmanial activity (Rodrigues et al., 2011). Licuri oil was also evaluated in the diets of cows and goats by Lima et al. (2011) and Silva et al. (2010).

The survey carried out by Folegatti (2012) with families of the cities of Boa Fé, Santa Luz and Valente (Bahia State) evaluated the consumption and daily intake of nutrients of the families. In the Sisal Territory, Semi-Arid region of Bahia State, the conditions for the production of foodstuffs are extremely unfavorable and among the cultivated crops, cassava (Manihot esculenta) is regularly used for many families as toasted flour. On the other hand, some native plants, such as licuri (Syagrus coronata) are also used for human consumption and around $37 \%$ of families use of licuri kernel to prepare candies and a milky extract. 
Although, the protein (1-3\%), lipid (0.1-0.3\% dry matter), minerals and vitamin contents are very low, cassava is the major carbohydrate source for around 500 million people in the world mainly in the developing countries (Montagnac et al., 2009).

This work was designed to assess the nutritional value of the fruit of the licuri collected in the Sisal Territory and the development of cookie formulations, using regional and underexplored raw materials. The nutritional value of food, including cookies, associated with global trends for a wider diversity of ingredients, is constantly pursued as a development goal. In this study, cassava flour and licuri kernel were used as a base for the formulations, evaluated by sensory analysis to expand the variety of foods for the population.

\section{Materials and methods}

\subsection{Material}

The palms of Syagrus coronata were selected in the cities of Valente, São Domingos and Santa Luz and one sample of licuri kernels was obtained in the fair of the city of Milagres, located in the Sisal Territory, Bahia State, Brazil. The access (A309BF5) was recorded in the Brazilian National System of Management of Genetic Heritage and Associated Traditional Knowledge (SisGen). The bunches were collected and the kernels were obtained after pulp removal and breaking of the endocarp, followed by drying. The kernels were mixed in order to obtain one sample by each city. The nutritional evaluation of kernels was carried out and the result was reported as average of the four samples. The kernels for the essay of cookies production was obtained by sampling of the samples from the bunches. The analysis of kernels and cookies was performed in duplicate. The cassava flour and the ingredients for the cookies were bought as commercial samples in the local market of the city of Cruz das Almas and presented nutritional labelling (Bahia State).

\subsection{Proximate composition and mineral content}

The proximate analysis of Syagrus coronata kernels and the cookies were performed according to AOAC Official methods (Association of Official Analytical Chemists, 2010). The moisture was carried out by drying in an oven at $105^{\circ} \mathrm{C}$ to constant weight (AOAC 925.09), the ash content was measured at $550^{\circ} \mathrm{C}$ in a muffle furnace (AOAC $923.03 / 32.1 .05$ ). The protein content was calculated based on nitrogen content determined by Kjeldahl method and the factor of 5.75 reported for vegetable products by Brazilian nutritional labeling regulation was used (Brasil, 2020). The total dietary fiber was determined by the enzymatic-gravimetric method (AOAC 992.16/32.1.18). The oil extraction from kernels was carried out in Soxhlet apparatus (petroleum ether $30-60{ }^{\circ} \mathrm{C}$ ) for 16 hours. The lipids of cookies were extracted according to acid hydrolysis followed by ethyl ether and petroleum ether extraction (AOAC 922.06/32.1.14F). The carbohydrates and calories were calculated according to Brazilian nutritional labeling regulation (Brasil, 2020).

The mineral content was evaluated for kernels and cookies by microwave-assisted wet digestion (Millestone) (AOAC 999.10) or after ash determination (AOAC 999.11), followed by ICP-OES
(Inductively coupled plasma - optical emission spectrometry) analysis according to Freitas et. al. (2015).

\subsection{Fatty acid and sterol composition}

For fatty acid profile analysis of kernel oils, the methyl esters were prepared according to Hartman \& Lago (1973) and analyzed by gas chromatography on an Agilent 6890 equipment equipped with a fused silica capillary column covered with a cyanopropylsiloxane film $(60 \mathrm{~m} \times 0.32 \mathrm{~mm} \times 0.25 \mu \mathrm{m})$ and temperature program as described: initial temperature of $100{ }^{\circ} \mathrm{C}$ for three min; from 100 to $150{ }^{\circ} \mathrm{C}$ with an increase of $50{ }^{\circ} \mathrm{C} / \mathrm{min}$; from 150 to $180^{\circ} \mathrm{C}$ with an increase of $1{ }^{\circ} \mathrm{C} / \mathrm{min}$; 180 to $200^{\circ} \mathrm{C}$ with an increase of $25^{\circ} \mathrm{C} / \mathrm{min}$, and at the final temperature of $200^{\circ} \mathrm{C}$ for $10 \mathrm{~min}$. The sample $(1 \mu \mathrm{L}$ of a $2 \%$ solution) was injected into an injector heated to $250{ }^{\circ} \mathrm{C}$ and operated in split mode (1:50). A flame ionization detector was kept at $280^{\circ} \mathrm{C}$. Identification was performed by comparing the retention times to NU-CHEK Prep, Inc. (Elysian, MN) standards and quantification was performed by internal normalization. The iodine and saponification indexes were calculated based on the fatty acid composition.

The fatty acid profile of cookies was performed according to AOAC Official method 996.06 (Association of Official Analytical Chemists, 2010) for lipid extraction. The fatty acid methyl esters preparation and gas chromatography analysis conditions were reported above. The quantification of fatty acid was conducted by using Triundecanoin as internal standard and the content of fatty acid was expressed by weight of the sample (cookies).

The sterol analysis of the oil was carried out after obtaining the unsaponifiable matter and the sterol fraction according to American Oil Chemists' Society (2009). The gas chromatography analysis was performed using an Agilent 6890 fitted with a methyl silicone ( $25 \mathrm{~m} \mathrm{x} 0.32 \mathrm{~mm} \times 0.17 \mu \mathrm{m})$ column, and oven temperatures was set at 260 to $290^{\circ} \mathrm{C}$ at $3^{\circ} \mathrm{C} / \mathrm{min}$. The injector and detector were kept at $300^{\circ} \mathrm{C}$. The quantification was performed by internal normalization.

\subsection{Formulation of cookies}

The dried ingredients (wheat and cassava flour) were mixed before the addition of the finely ground Syagrus coronata kernels. The shortening, margarine, glucose syrup and sucrose were mixed and the dried ingredients were added followed by water addition, according to the formulations reported in Table 1. The dough was mixed for 30 minutes and after 20 minutes the cookies were baked at $180^{\circ} \mathrm{C}$. Six formulations were previously evaluated and three were selected to sensory analysis. The cookies production was performed in agreement with the guidelines of Good Manufacturing Practice of Embrapa Cassava and Fruits (Cruz das Almas, Bahia State).

\subsection{Sensory analysis}

The sensory analysis was performed at the same day of the production of the cookies. The consumers (25) evaluated the cookies for overall acceptance, appearance, aroma, taste and texture attributes using a 9-point structured hedonic scale ranging 
from 1 (dislike extremely) to 9 (like extremely). The presentation followed a completely balanced design according to MacFie et al. (1989). Volunteers signed a consent form with the purpose of the study and the signature certified that they decide to participate and had read the information. The difference among formulations was evaluated by analysis of variance (ANOVA) and by Tukey test $(\mathrm{p}<0.05)$ using Statgraphics software (Manugistics, 1993).

\section{Results and discussion}

\subsection{Composition of Syagrus coronata kernels}

The proximate composition and minerals content of licuri kernels collected in Bahia State were presented in Table 2. The total dietary fiber (TDF) of licuri was $14.4 \mathrm{~g} / 100 \mathrm{~g}$ (wet basis - WB).

Table 1. Formulation of cookies using Syagrus coronata kernels and cassava flour.

\begin{tabular}{lccc}
\hline \multirow{2}{*}{\multicolumn{1}{c}{ Ingredient (grams) }} & \multicolumn{3}{c}{ Cookie formulation } \\
\cline { 2 - 4 } & $\mathrm{T} 1$ & $\mathrm{~T} 2$ & $\mathrm{~T} 3$ \\
\hline Wheat flour & 40.2 & 36 & 40.5 \\
Cassava flour & 4.5 & 9 & 4.5 \\
Syagrus coronata kernel & 10.1 & 10 & 5 \\
Vegetable Fat (shortening) & 5 & 5 & 10 \\
Sucrose & 13.1 & 13 & 13 \\
Margarine & 10 & 10 & 10 \\
Water & 15.1 & 15 & 15 \\
Glucose & 2 & 2 & 2 \\
\hline
\end{tabular}

Table 2. Proximate composition (g/100 g) and Minerals content (mg/100 g) of samples of Syagrus coronata kernels (wet basis).

\begin{tabular}{lc}
\hline \multicolumn{1}{c}{ Nutrients } & Average \pm SD \\
\hline Protein $^{1}$ & $9.3 \pm 0.6$ \\
Lípids & $63.4 \pm 2.0$ \\
Total dietary fiber & $14.4 \pm 0.9$ \\
Ashes & $1.7 \pm 0.2$ \\
Moisture & $5.7 \pm 1.8$ \\
Carbohydrates ${ }^{2}$ & $5.1 \pm 3.9$ \\
Calories (kcal/100 g) $\quad$ Minerals & $628.5 \pm 9.3$ \\
\hline & Average \pm SD \\
\hline Calcium & $31.7 \pm 6.2$ \\
Magnesium & $145.9 \pm 13.1$ \\
Phosphorus & $315.0 \pm 26.8$ \\
Potassium & $492.8 \pm 27$ \\
Manganese & $2.6 \pm 0.7$ \\
Iron & $4.0 \pm .2 .7$ \\
Sodium & $2.8 \pm 0.1$ \\
Zinc & $2.4 \pm 0.4$ \\
Copper & $1.0 \pm 0.1$ \\
Chromium & $\leq 0.07$ \\
Selenium & $\leq 0.2$ \\
Chumbo & $\leq 0.22$ \\
Aluminum & $\leq 9.6$ \\
Cobalt & $\mathrm{Nd}$ \\
Molybdenum & $\mathrm{Nd}$ \\
\hline${ }^{1}$ Protein content $=$ nitrogen $x$ 5.75; ${ }^{2}$ Carbohydrates $=100-($ moisture + protein + lipids + \\
& \\
total dietary fiber + ash). SD $=$ Standard deviation Nd $=$ not detected.
\end{tabular}

No comparison was possible due to the differences in methods of analysis employed for licuri kernels in the literature. However, the results obtained for licuri kernels were in the range of TDF of coconut kernel (9.5 and $17 \mathrm{~g} / 100 \mathrm{~g}$ (DW) as reported respectively by the Brazilian Composition Table (Universidade Estadual de Campinas, 2011) and Food Data Central of US Department of Agriculture (United States Department of Agriculture, 2020). It is noteworthy that licuri kernels showed higher results for TDF than cashew, Brazil nut, walnut, almond, and hazelnut varying from 4 to $12 \mathrm{~g} / 100 \mathrm{~g}$ (WB) (Universidade Estadual de Campinas, 2011; United States Department of Agriculture, 2020). The average oil content of licuri kernels of $63.4 \mathrm{~g} / 110 \mathrm{~g}$ (WB) or 67\% (DW) was similar to the results obtained by Crepaldi et al. (2001) and Paula et al. (2015) for licuri samples collected in the Brazilian states of Bahia and Minas Gerais State (63-69\% calculated as DW) but higher than the observed for the sample collected in Pernambuco State (34\% DW) by Silva et al. (2015). These results were reported for samples with higher moisture contents and the comparison was possible only on as dry basis.

Comparing licuri kernel with other palms of Arecaceae family, the oil content of babassu kernel (Attalea speciosa) (Santos et al., 2013), palm kernel (Elaeis guineensis) and copra (dried albumen of Cocos nucifera) which ranged from 62.5 to $67.5 \%, 46$ to $57 \%$ and 65 to- $68 \%$, respectively (Gunstone et al., 2007), agreed with the range obtained (61-66\%) in this study.

The average protein content $(9.3 \mathrm{~g} / 100-\mathrm{WB}$ or $9.9 \mathrm{~g} / 100 \mathrm{~g}-\mathrm{DW})$ was consistent with the large range of 5 to $16 \mathrm{~g} / 100 \mathrm{~g}$ (DW) observed for licuri kernel by Crepaldi et al. (2001), Silva et al. (2015) and Paula et al. (2015). Differences in reported results probably are due to differences related to the sites of collection such as soil composition and water availability. The protein content of licuri kernel was higher than the results for coconut kernel ( $\sim 6 \% \mathrm{DW})$ but lower than the figures observed for cashew, Brazil nut, almond, walnut, and hazelnut (14-21\%) (Universidade Estadual de Campinas, 2011; United States Department of Agriculture, 2020).

The ash content $(1.7 \mathrm{~g} / 100 \mathrm{~g}$ WB or $1.8 \mathrm{~g} / 100 \mathrm{~g} \mathrm{DW})$ was in the range of 1.5 to $3.7 \%$ (DW) reported by Crepaldi et al. (2001), Silva et al. (2015) and Paula et al. (2015). The average carbohydrates (calculated by difference) content was $5.1 \pm 3.9 \mathrm{~g} / 100 \mathrm{~g}$ and total calories $(628 \pm 9.3 \mathrm{kcal} / 100 \mathrm{~g})$ were in the range observed for oily kernels and nuts (Universidade Estadual de Campinas, 2011).

Regarding the minerals, the average contents of calcium, magnesium, phosphorus, potassium, manganese, zinc, and copper of licuri kernels were higher while sodium and potassium contents were lower than the results for coconut kernel reported by Universidade Estadual de Campinas (2011) and United States Department of Agriculture (2020), calculated as a dry basis. Although some mineral contents were lower than the observed for recognized sources of micronutrients such as almond, walnut, and hazelnut, the iron (4 $\pm 2.7 \mathrm{mg} / 100 \mathrm{~g})$, zinc $(2.4 \pm 0.4 \mathrm{mg} / 100 \mathrm{~g})$, magnesium $(146 \pm 13 \mathrm{mg} / 100 \mathrm{~g})$ and phosphorus contents $(315 \pm 27 \mathrm{mg} / 100 \mathrm{~g})$ of licuri kernel were in the range observed for these nuts varying from 3-9.7; $2.5-3.1 ; 158-270$ and $290-480 \mathrm{mg} / 100 \mathrm{~g}$, respectively (United States Department of Agriculture, 2020). The manganese $(2.6 \pm 0.7 \mathrm{mg} / 100 \mathrm{~g})$ and copper $(1 \pm 0.1 \mathrm{mg} / 100 \mathrm{~g})$ contents of 
licuri were in the range reported by Rodushkin et al. (2008) for almond, hazelnut, walnut, cashew and Brazil nuts, ranging from $1.3-5.8$ and $1.1-2.2 \mathrm{mg} / 100 \mathrm{~g}$, respectively. Selenium was detected only in two samples from $10-200 \mu \mathrm{g} / 100 \mathrm{~g}$ and the variation may be explained by differences in the soil. This occurrence was also observed by Freitas et al. (2008) in Brazil nut samples showing a range of $3 \mu \mathrm{g} / 100 \mathrm{~g}$ to $51.2 \mathrm{mg} / 100 \mathrm{~g}$. Aluminum content varied from not detected to $9.6 \mathrm{mg} / 100 \mathrm{~g}$ and lead was detected only in one sample $(0.22 \mathrm{mg} / 100 \mathrm{~g})$ and the results may be attributed not only to samples but also to residues during manipulation of fruits to remove pulp and endocarp for kernel recovery and its storage. Cobalt and molybdenum were not detected.

The kernels of Syagrus coronata is a valuable source of total dietary fiber, lipids and minerals such as copper, zinc, magnesium, manganese and phosphorus.

Syagrus coronata kernel oils showed a fatty acid profile similar to other commercial lauric oils such as coconut, palm kernel and babassu oils (Food and Agriculture Organization, 1999) which present medium-chain fatty acids from C6:0 to C14:0. The main fatty acids of licuri kernel oil were lauric - C12:0 (45.5-47.7\%), myristic - C14:0 (13.7-15.9\%), oleic - C18:1 (9.1-11.7\%), caprylic - C8:0 (6.7-11.4\%), capric - C10:0 (5.7-9.7\%) and linoleic - C18:2 (2.6-2.9\%) (Table 3). The results were in agreement with results for pressed licuri oil reported by Bauer et al. (2013) but showed differences from the sample of Pernambuco State evaluated by Silva et al. (2015) in which caprylic and linoleic acids were not detected. The saturated fatty acids comprised around $87 \%$ of total fatty acids and the lower contents of monounsaturated $(10 \%)$ and polyunsaturated fatty acids $(\sim 3 \%)$ resulted in low Iodine Value (13-15 g/100 g). Likewise, the Saponification Value (242-252 $\mathrm{mg} \mathrm{KOH} / \mathrm{g}$ ) obtained was in the range of commercial lauric oils (Food and Agriculture Organization, 1999).

Other kernel oils of Arecaceae family also presented similar profile such as Astrocaryum vulgare (Bora et al., 2001) and Astrocaryum aculeatum (Didonet et al., 2020), Acrocomia lasiospatha, Bactris gasipaes, Elaeis oleifera, Maximiliana maripa (Bereau et al., 2003), and Acrocomia aculeata (Antoniassi et al., 2020). These oil sources from Brazilian biodiversity are poorly exploited while there is small scale production of licuri kernel oil (Bauer et al., 2013; Gomes et al., 2018).

Among the commercial lauric oils, around $60 \%$ of palm kernel oil is used for the production of fatty acids, fatty alcohols, and methyl esters (Rupilius \& Ahmad, 2007) while coconut oil is utilized as cooking oil, nutritional supplement, cosmetics and biofuel (Coconut oil boom, 2016).

The high oil content of licuri kernel, the feasibility of oil extraction by pressing of other lauric oils and their broad spectrum of applications indicated that licuri kernel oil may be a successful product of Brazilian biodiversity and a source of income for the collectors.

Regarding sterol profile of kernel oil of licuri samples (Table 3), the main sterol was beta-sitosterol (62.4\%), followed by Campesterol (14\%), Delta-5-avenasterol (12,1\%), and Stigmasterol (7.2\%), in agreement with the ranges observed for commercial lauric oils according to the Codex Alimentarius (Food and Agriculture Organization, 1999). Cholesterol was detected up
Table 3. Fatty acid composition (g fatty acid/total fatty acid) and Sterol profile of oil from Syagrus coronata kernels (g sterol/total sterols).

\begin{tabular}{|c|c|c|}
\hline Fatty acid & Average \pm SD & Lauric oils ${ }^{1}$ (range) \\
\hline C6:0 & $\leq 0.36$ & $\leq 0.8$ \\
\hline $\mathrm{C} 8: 0$ & $9.2 \pm 2.6$ & $2.4-10$ \\
\hline C10:0 & $6.6 \pm 0.7$ & $1.2-8$ \\
\hline $\mathrm{C} 12: 0$ & $46.1 \pm 1.1$ & $40-55$ \\
\hline C14:0 & $14.6 \pm 1.0$ & $11-27$ \\
\hline C16:0 & $6.5 \pm 0.7$ & $5.2-11$ \\
\hline C18:0 & $3.5 \pm 0.6$ & $1-7.4$ \\
\hline C18:1 & $10.3 \pm 1.1$ & $5-20$ \\
\hline $\mathrm{C} 18: 2$ & $2.8 \pm 0.2$ & $1-6.6$ \\
\hline C20:0 & $\leq 0.06$ & $\leq 0.8$ \\
\hline$\Sigma$ Saturated fatty acids & $86.70 \pm 1.0$ & - \\
\hline$\Sigma$ Monounsaturated fatty acids & $10.30 \pm 1.1$ & - \\
\hline$\Sigma$ Polyunsaturated fatty acids & $2.78 \pm 0.2$ & - \\
\hline $\begin{array}{l}\text { Saponification value } \\
(\mathrm{mg} \mathrm{KOH} / \mathrm{g})\end{array}$ & $247.3 \pm 4.7$ & $230-265$ \\
\hline Iodine value $(\mathrm{g} / 100 \mathrm{~g})$ & $13.7 \pm 1.2$ & $6.3-21$ \\
\hline Sterol & Average \pm SD & Lauric oils ${ }^{1}$ (range) \\
\hline Cholesterol & $\leq 1.64$ & $\leq 3.7$ \\
\hline Campesterol & $14.0 \pm 0.7$ & $6-18.7$ \\
\hline Stigmasterol & $7.2 \pm 0.5$ & $8.7-16.6$ \\
\hline Beta-Sitosterol & $62.4 \pm 3.7$ & $32.6-73.1$ \\
\hline Delta-5-avenasterol & $12.1 \pm 2.7$ & $1.4-40.5$ \\
\hline Delta-7-stigmastenol & $0.4 \pm 0.3$ & $\leq 3$ \\
\hline Delta-7-avenasterol & $\leq 1.02$ & $\leq 3$ \\
\hline
\end{tabular}

${ }^{1}$ Coconut, babassu and palm kernel oils (Codex Alimentarius, CXS 210, 2013). $\mathrm{SD}=$ Standard deviation. Saturated fatty acids $(\mathrm{C} 6: 0+\mathrm{C} 8: 0+\mathrm{C} 10: 0+\mathrm{C} 12: 0+\mathrm{C} 14: 0+\mathrm{C} 16$ :0:0+C18:0+ C20:0); Monounsaturated fatty acids (C18:1); Polyunsaturated fatty acids (C18:2).

to $1.6 \%$. The sterol profile is useful to identify adulteration with other vegetable oils (Antoniassi et al., 1998) as well as the fatty acid profile and as far as we know this is the first result of sterols for Syagrus coronata kernel oil.

\subsection{Composition and sensory evaluation of cookies}

The composition of cookies prepared with cassava flour and licuri kernel was presented in Tables 4 and 5. There were slight differences among the cookies formulation related to protein (6.3-6.8 g/100 g), lipids (21.6-24.1 g/100 g), ashes (0.7-0.8 g/100 g) owing to the contribution of wheat flour (around 36-40\%), the vegetable fat (shortening and margarine) addition from 15 to $20 \%$ and the concentration of licuri kernel ( 5 and $10 \%$ ) in the formulations. Cassava flour is a traditional Brazilian product used elsewhere in the country showing low protein and oil contents but TDF was reported as around $\sim 6 \%$ (Universidade Estadual de Campinas, 2011). The total dietary fiber (3.1-3.5 g/100 g) of cookies showed the contribution of licuri kernel and cassava flour because the TDF content of wheat flour is low ( 2.3\%) (Universidade Estadual de Campinas, 2011). The carbohydrates content (62.3 to $63.5 \mathrm{~g} / 100 \mathrm{~g}$ ) was the main nutrient because wheat and cassava flour are sources of starch and besides the fat addition, the total calories varied from 475 to $492 \mathrm{kcal} / 100 \mathrm{~g}$. 
Table 4. Proximate composition (g/100 g) and Mineral content (mg/100 g) (wet basis) of cookies using Syagrus coronata kernels and cassava flour.

\begin{tabular}{lccc}
\hline \multirow{2}{*}{\multicolumn{1}{c}{ Nutrient }} & \multicolumn{3}{c}{ Cookie formulation } \\
\cline { 2 - 4 } & $\mathrm{T} 1$ & $\mathrm{~T} 2$ & $\mathrm{~T} 3$ \\
\hline Protein $^{1}$ & 6.81 & 6.33 & 6.41 \\
Lípids & 21.59 & 24.13 & 23.58 \\
Total dietary fiber & 3.52 & 3.21 & 3.1 \\
Ashes & 0.8 & 0.78 & 0.73 \\
Moisture & 3.8 & 3.23 & 3.1 \\
Carbohydrates $^{2}$ & 63.48 & 62.32 & 63.08 \\
Calories (kcal/100 g) $_{\text {Mineral }}$ & 475.47 & 491.77 & 490.18 \\
Sodium & $\mathrm{T} 1$ & $\mathrm{~T} 2$ & $\mathrm{~T} 3$ \\
Potassium & 160.96 & 146.28 & 152.01 \\
Phosphorus & 151.57 & 150.15 & 118.52 \\
Magnesium & 97.98 & 91.66 & 80.58 \\
Calcium & 32.17 & 30.89 & 24.92 \\
Iron & 21.54 & 17.42 & 17.82 \\
Zinc & 2.39 & 2.27 & 2.48 \\
Manganese & 1.64 & 1.39 & 1.22 \\
Aluminum & 0.81 & 0.75 & 0.67 \\
Copper & 0.58 & 0.54 & 0.5 \\
Chromium & 0.32 & 0.31 & 0.23 \\
\hline
\end{tabular}

${ }^{1}$ Protein content $=$ nitrogen $\mathrm{x} 5.75 ;{ }^{2}$ Carbohydrates $=100-($ moisture + protein + lipids + total dietary fiber+ ash)

Table 5. Fatty acids of cookies formulations ( $\mathrm{g}$ fatty acid/100 $\mathrm{g}$ of product).

\begin{tabular}{|c|c|c|c|}
\hline \multirow[t]{2}{*}{ Fatty acid } & \multicolumn{3}{|c|}{ Cookie formulation } \\
\hline & $\mathrm{T} 1$ & $\mathrm{~T} 2$ & T3 \\
\hline C8:0 & 0.56 & 0.49 & 0.34 \\
\hline C10:0 & 0.45 & 0.48 & 0.28 \\
\hline C12:0 & 3.82 & 3.33 & 1.88 \\
\hline C14:0 & 1.24 & 1.07 & 0.60 \\
\hline C16:0 & 2.39 & 2.54 & 2.44 \\
\hline C18:0 & 1.52 & 1.69 & 1.66 \\
\hline $\mathrm{C} 18: 1$ trans isomers & 2.35 & 3.02 & 3.16 \\
\hline C18:1 cis-9 & 3.92 & 4.28 & 4.09 \\
\hline C18:1 cis-11 & 0.32 & 0.39 & 0.41 \\
\hline $\mathrm{C} 18: 2$ trans trans isomers & 0.08 & 0.10 & 0.11 \\
\hline C18:2 cis trans isomers & nd & 0.09 & 0.14 \\
\hline C18:2 & 4.31 & 4.50 & 4.67 \\
\hline C20:0 & 0.06 & 0.07 & 0.07 \\
\hline C18:3 & 0.38 & 0.38 & 0.40 \\
\hline C22:0 & 0.07 & 0.08 & 0.08 \\
\hline C24:0 & nd & nd & 0.03 \\
\hline$\Sigma$ Saturated fatty acid & 9.83 & 9.75 & 7.36 \\
\hline$\Sigma$ Monounsaturated fatty acids & 4.24 & 4.67 & 4.51 \\
\hline$\Sigma$ Polyunsaturated fatty acids & 4.69 & 4.89 & 5.07 \\
\hline$\Sigma$ Total trans isomers & 2.43 & 3.16 & 3.41 \\
\hline
\end{tabular}

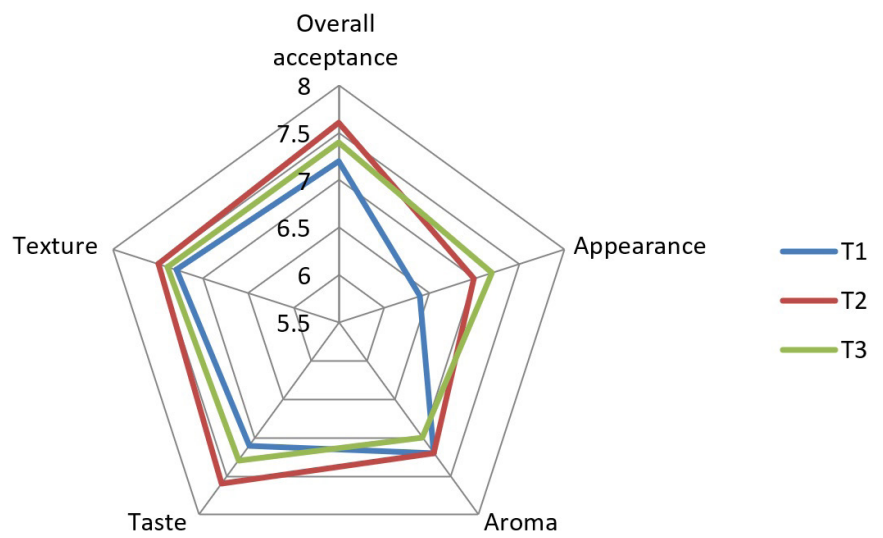

Figure 1. Consumer acceptance scores for sensory attributes and overall liking ${ }^{1}$ of cookies with Syagrus coronata kernel and cassava flour. ${ }^{1}$ Structured hedonic scales - 1 (dislike extremely) to 9 (like extremely).

The mineral results displayed the high contribution of wheat flour and the iron content observed $(2.3-2.5 \mathrm{mg} / 100 \mathrm{~g})$ was due to the mandatory fortification of wheat flour with this micronutrient in Brazil. The sodium content (146-161 mg/100 g) was related to margarine (salted) addition. The zinc content (1.2 to $1.6 \mathrm{mg} / 100 \mathrm{~g}$ ) showed the contribution of licuri kernel since the wheat flour and cassava flour presented $\mathrm{Zn}$ contents below $0.8 \mathrm{mg} / 100 \mathrm{~g}$ (Universidade Estadual de Campinas, 2011).

The fatty acid composition of cookies showed the contribution of licuri kernel as a source of C8-C14 fatty acids which were lower at T3 - formulation because of the lower content of this ingredient. The presence of trans isomers of C18:1 and C18:2 fatty acids totaling from 2.4 to $3.4 \mathrm{~g} / 100 \mathrm{~g}$ of cookies indicated the presence of partially hydrogenated vegetable oil, probably from the shortening. The Brazilian regulation related to nutritional facts demands the claim of trans fat and saturated fat (Brasil, 2020) and the limit to be adopted by January 2023 will be $2 \mathrm{~g}$ of trans fat per $100 \mathrm{~g}$ of total fat (Brasil, 2019). The sum of saturated fatty acids (7.3-9.8 $\mathrm{g} / 100 \mathrm{~g}$ of cookies) was higher than the sum of monounsaturated $(4.2-4.7 \mathrm{~g} / 100 \mathrm{~g})$ and polyunsaturated fatty acids (4.7-5.1 g/100 $\mathrm{g}$ of cookies) and displayed the presence of partially hydrogenated soybean oil. The main fatty acids were oleic C18:1 cis-9 (3.9-4.3 g/100 g) and linoleic (4.3-4.7 g/100 g of product).

The scores observed for the three cookie formulations evaluated for overall acceptance and the attributes taste, texture, aroma, and appearance (7-7.6) were in the region of "liked very much" and "like moderately" of the hedonic scale except for the score for the appearance of the formulation T1 (6.4). No difference was observed $(p<0.05)$ for overall acceptance and the attributes evaluated. However, the formulation T2, presenting the higher licuri (10\%) and cassava flour contents (9\%), showed a trend of the highest overall acceptance, aroma, taste, and texture scores (Figure 1). The appearance score was higher for $\mathrm{T} 3$ and a similar score observed for aroma was achieved by $\mathrm{T} 1$ and $\mathrm{T} 2$ formulations. 
The results point out the application of licuri kernel as an ingredient of food products besides the traditional application as candies and aqueous extract for cooking.

\section{Conclusion}

Syagrus coronata showed potential as a product of Brazilian biodiversity since the kernels are a valuable source of total dietary fiber, lipids, and minerals such as copper, zinc, magnesium, manganese, and phosphorus. The licuri kernel oil presented a similar profile to other lauric oils in relation to the composition in fatty acids and sterols. In addition, the kernels are feasible as an ingredient in the preparation of cookies, as indicated by consumer acceptance and considering that they are a traditional raw material that can be further leveraged.

\section{Acknowledgements}

The authors thank to CNPq (Conselho Nacional de Desenvolvimento Científico e Tecnológico) which provided the financial support to the project "Desenvolvimento de tecnologias de processamento de produtos da agricultura familiar do Semi-Árido baiano, visando à agregação de valor e à melhoria da qualidade alimentar das comunidades rurais" (processo $\mathrm{n}^{\circ}$ 50.3854/2003-4). The authors are grateful to Silvana Pedroso de Oliveira (in memoriam) for the contribution to the project.

\section{References}

American Oil Chemists' Society - AOCS. (2009). Official methods and recommended practices of the American Oil Chemists' Society. Champaign, IL: AOCS.

Andrade Martins, W., Ramos, M. A., Souto, W. M. S., Bento-Silva, J. S., Paulino, U. A., \& Araújo de Lima, E. (2015). Knowledge, uses and practices of the licuri palm (Syagrus coronata (Mart.) Becc.) around protected areas in northeastern Brazil holding the endangered species Lear's Macaw (Anodorhynchus leari). Tropical Conservation Science, 8(4), 893-911. http://dx.doi.org/10.1177/194008291500800403.

Antoniassi, R., Freitas, S. C. D., Silva, T. D. S., Santiago, M. C. P. D. A., Wilhelm, A. E., \& Junqueira, N. T. V. (2020). Impact of genotype on fatty acid profile, oil content and nutritional value of the sweet fruits of Acrocomia aculeata. Revista Brasileira de Fruticultura, 42(6), e-796. http://dx.doi.org/10.1590/0100-29452020796.

Antoniassi, R., Pereira, D. A., Szpiz, R. R., Jablonka, F. H., \& Lago, R. C. (1998). Avaliação das características de identidade e qualidade de amostras de azeite de oliva. Brazilian Journal of Food Technology, $1(1-2), 32-43$.

Association of Official Analytical Chemists - AOAC. (2010). Official methods of analysis of AOAC International (18th ed.). Washington, DC: AOAC.

Bauer, L. C., Damásio, J. M. A., Silva, M. V., Santana, D. D. A., Gualberto, S. A., \& Simionato, J. I. (2013). Chemical characterization of pressed and refined licuri (Syagrus coronata) oils. Acta Scientiarum. Technology, 35(4), 771-776. http://dx.doi.org/10.4025/actascitechnol.v35i4.20251.

Bereau, D., Benjelloun-Mlayah, B., Banoub, J., \& Bravo, R. (2003). FA and unsaponifiable composition of five Amazonian palm kernel oils. Journal of the American Oil Chemists' Society, 80(1), 49-53. http:// dx.doi.org/10.1007/s11746-003-0649-5.

Bora, P. S., Narain, N., Rocha, R. V. M., Oliveira Monteiro, A. C., \& Azevedo Moreira, R. (2001). Characterisation of the oil and protein fractions of tucuma (Astrocaryum Vulgare Mart.) fruit pulp and seed kernel (Astrocaryum Vulgare Mart.). CYTA: Journal of Food, 3, 111-116.

Brasil, Agência Brasileira de Vigilância Sanitária. (2019, December 26). Define os requisitos para uso de gorduras trans industriais em alimentos (Resolução da Diretoria Colegiada (RDC) n 332, de 23 de dezembro de 2019). Diário Oficial [da] República Federativa do Brasil.

Brasil. (2020, October 9). Estabelece os requisitos técnicos para declaração da rotulagem nutricional nos alimentos embalados (Instrução normativa $\mathrm{n}^{\circ} 75$, de 8 de outubro de 2020). Diário Oficial [da] República Federativa do Brasil.

Crepaldi, I. C., Almeida-Muradian, L. D., Rios, M. D. G., Penteado, M. V. C., \& Salatino, A. (2001). Composição nutricional do fruto de licuri (Syagrus coronata (Martius) Beccari). Revista Brasileira de Botânica, 24(2), 155-159. http://dx.doi.org/10.1590/S010084042001000200004 .

Crepaldi, I. C., Salatino, A., \& Rios, A. (2004). Syagrus coronata and Syagrus vagans: traditional exploitation in Bahia, Brazil. PalmsLawrence, 48(1), 43-48.

Didonet, A. A., Antoniassi, R., Back, G. R., Faria-Machado, A. F., Wilhelm, A. E., \& Ferraz, I. D. K. (2020). Characterization of amount and quality of tucuman kernel oil as a potential biomass. Journal of the American Oil Chemists' Society, 97(9), 955-962. http://dx.doi. org/10.1002/aocs.12374.

Folegatti, M.I.S.M. (2012). Report to CNPq of the Project "Desenvolvimento de tecnologias de processamento de produtos da agricultura familiar do Semi-Árido baiano, visando à agregação de valor e à melhoria da qualidade alimentar das comunidades rurais" (processo $n^{\circ}$ 50.3854/2003-4). Embrapa.

Food and Agriculture Organization - FAO. (1999). CXS 210: standard for named vegetable oils. Codex Alimentarius Adopted 1999, Revised 2019, Amended 2019. Rome. Retrieved from http://www.fao.org/ fao-who-codexalimentarius/codex-texts/list-standards/en/

Freitas, S. C., Marcatto, J. D. O. S., Simas, E. S., Santos Silva, T., \& Conte, C. (2015). Método de digestão por via úmida para determinação de microelementos e elementos traços por espectrometria de emissão óptica em vinhos (Documentos, No. 122). Rio de Janeiro: Embrapa Agroindústria de Alimentos. Retrieved from https://www.infoteca. cnptia.embrapa.br/infoteca/handle/doc/1039724

Freitas, S. C., Gonçalves, E. B., Antoniassi, R., Felberg, I., \& Oliveira, S. P. (2008). Meta-analysis of selenium content in Brazil nuts. Brazilian Journal of Food Technology, 11, 54-62.

Gomes, F. M., Ribeiro, R. T. M., Batista, M. E. P., Souza, E. N., Siqueira, J. A. Fo., Portela, S., Castro, R., \& Loiola, M. I. B. (2018). Espécies oleaginosas e ceríferas nativas da região nordeste: Syagrus coronata. In L. Coradin, J. Camillo, F. G. C. Pareyn (Eds.), Espécies nativas da flora brasileira de valor econômico atual ou potencial: plantas para o futuro: região nordeste. Brasília: Ministério do Meio Ambiente, Secretaria de Biodiversidade.

Gunstone, F. D., Harwood, J. L., \& Padley, F. B. (2007). The lipid handbook (3rd ed.). London: Chapman \& Hall.

Hartman, L., \& Lago, R. C. A. (1973). Rapid preparation of fatty acid methyl esters from lipids. Laboratory Practice, 22(6), 475-476, passim. PMid:4727126.

Lima, L. D. S., Oliveira, R. L., Bagaldo, A. R., Garcez, A. F. No., Ribeiro, C. V. D. M., \& Lanna, D. P. D. (2011). Composition and fatty acid profile of milk from cows on pasture subjected to licuri oil supplement. Revista Brasileira de Zootecnia, 40(12), 2858-2865. http://dx.doi. org/10.1590/S1516-35982011001200033. 
Lima-Rufino, R. M. U., Medeiros-Costa, J. T., Silva, V. A., \& Andrade, L. D. H. C. (2008). Conhecimento e uso do ouricuri (Syagrus coronata) e do babaçu (Orbignya phalerata) em Buíque, PE, Brasil. Acta Botanica Brasílica, 22(4), 1141-1149. http://dx.doi.org/10.1590/ S0102-33062008000400025.

MacFie, H. J. H., Bratchell, N., Greenhoff, K., \& Vallis, L. V. (1989). Designs to balance the effect of order of presentation and first-order carry-over effects in hall tests. Journal of Sensory Studies, 4(1), 129148. http://dx.doi.org/10.1111/j.1745-459X.1989.tb00463.x.

Manugistics. (1993). Statgraphics reference manual. Rockville: Manugistics.

Montagnac, J. A., Davis, C. R., \& Tanumihardjo, S. A. (2009). Nutritional value of cassava for as a staple food and recent advances for improvement. Comprehensive Reviews in Food Science and Food Safety, 8(3), 181-194. http://dx.doi.org/10.1111/j.1541-4337.2009.00077.x. PMid:33467798.

Paula, G. X. D. Fo, Barreira, T. F., Rodrigues, V. C. D. C., Cardoso, L. D. M., \& Martino, H. S. D. (2015). Study of the physical and physicochemical characteristics of fruits of the licuri palm (Syagrus coronata (Mart.) Becc.) found in the Atlantic Forest of Minas Gerais, Brazil. Food Science and Technology, 35(3), 474-480. http://dx.doi. org/10.1590/1678-457X.6652.

Rodrigues, I. A., Alviano, D. S., Gomes, M. T., Silva, D. O., Antoniassi, R., Silva, A. J. R., Bizzo, H. R., Alviano, C. S., Vermelho, A. B., \& Rosa, M. S. S. (2011). In vitro anti-Leishmania amazonensis activity of the polymeric procyanidin-rich aqueous extract from Syagrus coronata. Journal of Medicinal Plants Research, 5(16), 3781-3790.

Rodushkin, I., Engström, E., Sörlin, D., \& Baxter, D. (2008). Levels of inorganic constituents in raw nuts and seeds on the Swedish market. The Science of the Total Environment, 392(2-3), 290-304. http://dx.doi.org/10.1016/j.scitotenv.2007.11.024. PMid:18155749.

Rupilius, W., \& Ahmad, S. (2007). Palm oil and palm kernel oil as raw materials for basic oleochemicals and biodiesel. European Journal of Lipid Science and Technology, 109(4), 433-439.
Santos, D. S., Silva, I. G. D., Araújo, B. Q., Lopes, C. A. Jr., Monção, N. B., Citó, A. M., Souza, M. H. S. L., Nascimento, M. D. S. B., \& Costa, M. C. P. (2013). Extraction and evaluation of fatty acid compositon of Orbignya phalerata Martius Oils (Arecaceae) from Maranhão State, Brazil. Journal of the Brazilian Chemical Society, 24, 355-362.

Santos-Moura, S. S., Gonçalves, E. P., Melo, L. D. F. A., Paiva, L. G., \& Silva, T. M. (2016). Morphology of fruits, diaspores, seeds, seedlings, and saplings of Syagrus coronata (Mart.) Becc. Bioscience Journal, 32(3), 652-660. http://dx.doi.org/10.14393/BJ-v32n3a2016-32829.

Silva, R. B., Silva-Junior, E. V., Rodrigues, L. C., Andrade, L. H., Silva, S. I., Harand, W., \& Oliveira, A. F. (2015). A comparative study of nutritional composition and potential use of some underutilized tropical fruits of Arecaceae. Anais da Academia Brasileira de Ciências, 87(3), 1701-1709. http://dx.doi.org/10.1590/0001-3765201520140166. PMid:26221983.

Silva, T. M., Oliveira, R. L., Barbosa, L. P., Garcez, A. F. No., Bagaldo, A. R., Jesus, I. B. D., Macome, F. M., \& Ribeiro, C. V. D. M. (2010). Componentes corporais de caprinos jovens 3/4 Boer submetidos a dietas com óleo de licuri (Syagrus coronata). Arquivo Brasileiro de Medicina Veterinária e Zootecnia, 62(6), 1448-1454. http://dx.doi. org/10.1590/S0102-09352010000600022.

Soares, K. P. (2020). Syagrus. In Jardim Botânico do Rio de Janeiro - JBRJ (Ed.), Flora do Brasil 2020. Rio de Janeiro: JBRJ.Retrieved from http://floradobrasil.jbrj.gov.br/reflora/floradobrasil/FB15736

United States Department of Agriculture - USDA. (2020). FoodData Central. Retrieved from https://fdc.nal.usda.gov/ -app.html\#/fooddetails/784378/nutrients

Universidade Estadual de Campinas - UNICAMP (2011). TACO: tabela brasileira de composição de alimentos (4. ed. rev. e ampl., 161 p.). Campinas: NEPA UNICAMP. Retrieved from https://www.cfn.org.br/ wp-content/uploads/2017/03/taco_4_edicao_ampliada_e_revisada.pdf 